\title{
Does Family Involvement Matter in Initial Public Offering Underpricing? Evidence from Saudi Arabia
}

\author{
"Dalal Alrubaishi ${ }^{1}$ \\ Ghadah Alarifi ${ }^{1}$
}

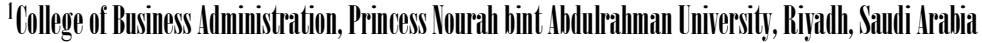

The phenomenon of initial public offering (IPO) underpricing has been extensively researched in the literature, however, the underpricing of family firms has received little attention. This is even more prevalent when it comes to underpricing of family firms in an emerging market such as the Saudi Arabian market. This study explores the IPO underpricing phenomenon of firms that went public in the Saudi stock market with the aim of determining if there is any significant difference in underpricing between family and non-family firms. The study utilized prospect theory and stewardship theory as its theoretical framework and used family involvement in ownership and management as a proxy of family firms. Based on collected data set of first day trading price of 77 firms during 2007-2018 period and using ordinary least squares (OLS) hierarchical regression, the study found that family firms are negatively and significantly related to IPO underpricing. The study contributes to both family business and IPO underpricing literature by showing the effect of family involvement in stock valuation at the listing stage.

Keywords: Family firms, initial public offering, family involvement, underpricing, Saudi Arabia, emerging markets

JEL: G12, G24, G32
\end{abstract}

Family firms are the dominant form of organizations in the world (Kotlar et al., 2018; La Porta, Lopez-de-Silanes and Shleifer, 1999). They are the prime source of wealth creation and employment for both developed and emerging economies (Bertrand and Schoar, 2006). Family firms constitute of around 70 percent of all organizations in the U.S. (Minichilli, Brogi and Calabrò, 2016), and Asia (Ramadani and Gërguri-Rashiti, 2017). This is also true in Saudi Arabia, where 63 percent of all companies are family owned, contributing to 32 percent of the country's gross domestic product (GDP) (Ministry of Commerce and Investment, 2018). While family businesses prevail in privately held firms, they are largely present among listed companies (Bertrand and Schoar, 2006; Mullins and Schoar, 2016). Furthermore, the notion that publicly listed family firms outperform their counterparts in emerging markets have long been acknowledged by researchers (Duran et al., 2019).

In the family business literature, no universally accepted definition has been provided for what actually constitutes a family business. While some scholars adopted a broad definition, considering family firms as those who identify themselves as such (e.g., Cruz and Nordqvist, 2012; Naldi et al., 
International Journal of Management, Economics and Social Sciences

2007; Zahra et al., 2008). Others adopted a narrower description, defining family firms in terms of involvement in ownership or management (Eddleston, Kellermanns and Zellweger, 2012; Schepers et al., 2014). As such, Miller et al. (2007) called for a more refined measure to distinguish family from non-family firms when investigating their performance. This is one of the few studies of IPO underpricing that define family involvement based on involvement in both ownership and management. Underpricing is the substantial jump of share price in the first day of trading (Ljungqvist, 2007). The phenomenon of IPO underpricing has been extensively researched in different markets in the literature; however, the underpricing of family firms has received little attention (Cirillo, Romano and Ardovino, 2015; Leitterstorf and Rau, 2014). This is even more prevalent when it comes to underpricing of family firms in an emerging market such as the Saudi market. Consequently, this study aims at answering the research question "What is the effect of family involvement in ownership and management in IPO underpricing in the Saudi market?"

This study contributes to the family business literature by showing the effect of family involvement in ownership and management on stock valuation at the listing stage using a dual theoretical model combing prospect theory and stewardship theory to support the findings. The research also contributes to the IPO underpricing literature by showing the influence of ownership structure on the first-day returns of IPOs in the Saudi market. This study has responded to calls for, empirical studies on family ownership effecting the IPO underpricing (Cirillo et al., 2015), family involvement and IPO underpricing relationship (Chandler et al., 2019), and the differences between family firms and non-family firms in IPO valuation (Westin and Wiklund, 2016).

The structure of this paper is as follows: The first section provides a related literature review and theoretical background. The second section outlines the research method and data used in this study. The third section contains results of the regression analyses and the discussions. The fourth section includes the conclusion.

\section{LITERATURE REVIEW}

Initial Public Offering (IPO) is a significant milestone in the journey of any firm. Offering shares to the public enable the firm to raise new capital and create value for the firm in the stock market (Daugherty and Jithendranathan, 2012). For family firms, going public enhance the effectiveness of succession and professionalism issues in the family firm (Lien and Li, 2014; Sonfield and Lussier, 2004). However, the downside of going public to family firms is the threat of losing family control over the firm (Daugherty and Jithendranathan, 2012).

One phenomenon that is usually associated with IPO is the increase of share value from the initial offering price at the first day closing price, that is commonly known as IPO underpricing. The phenom- 


\section{Alrubaishi \& Alarifi}

enon of IPO underpricing has been extensively researched in different markets around the world (AIHassan, Delgado and Omran, 2010; Filatotchev and Bishop, 2002; Kiymaz, 2000; Ljungqvist, 2007). In their study of IPOs international insight, Loughran, Ritter and Rydqvist (1994) included 54 countries from around the world and found that average initial returns are as low as 3.3 percent for Russia and as high as 270.1 percent for UAE, with the U.S. having 16.9 percent initial return.

When it comes to underpricing, there exists no definite answer to the question of why shares are sold at a discount (Leitterstorf and Rau, 2014). Several theories have been utilized in the literature to understand the phenomenon of IPO underpricing. Ljungqvist (2007) reviewed major theories of underpricing and grouped them in four broad categories-asymmetric information, institutional, control, and behavioral-with asymmetric information having the foremost effect based on empirical evidence. Asymmetric information is based on the notion that one of the key parties involved in IPO transactions (the issuing firm, the underwriter, and the investors) knows more than the others. This asymmetry may lead to agency conflict between the underwriter and the issuing firm and result in higher underpricing (Loughran and Ritter, 2002). The issuing firm's goal is to maximize the gross proceeds, but this might not be an optimal option for the issuing agent to avoid issue undersubscription.

When it comes to family firms, the literature is inconclusive regarding the relationship between family involvement and first-day underpricing of IPOs (Kotlar et al., 2018). Drawing on the behavioral agency model and utilizing family involvement in ownership to define family firms, Leitterstorf and Rau (2014) found that the underpricing of family firms in Germany is higher than that of non-family firms in first-day trading. However, by extending Leitterstorf and Rau's model to other European countries, Signori et al. (2015) found that the relationship between family firms and IPO underpricing is not significant. Moreover, drawing on the agency theory and measuring family control and ownership in the U.S., Daugherty and Jithendranathan (2012) found that family firms experience less underpricing in first-day trading when compared to non-family firms. Much of these contradictory results are because of the definition used to identify family firms (Cirillo et al., 2015), and the geographical or temporal context of the research (Signori et al., 2015).

The two dominant theories utilized in the literature to investigate family business performance are the agency theory and stewardship theory (Le Breton-Miller, Miller and Lester, 2011). According to agency theory, owners (principal) give authority to managers (agent), which empowers them to make decisions that affect the wealth of the owners. The result of this is that agency costs can arise in firms due to the conflict of interests between the agent and the principal (Fama and Jensen, 1983; Jensen and Meckling, 1976). However, agency costs in firms can be reduced by concentrated ownership (Fama and Jensen, 1983; Jensen and Meckling, 1976). Owner-managers may even act as monitors 
of the firm (Anderson, Duru and Reeb, 2009; Combs et al., 2010). This has led to many scholars arguing that agency costs will be reduced or removed in family firms because the manager and owner is often the same person (Chrisman, Chua and Litz, 2004; Sharma, 2004). As such the agency theory only explains family firm performance to a limited degree (Corbetta and Salvato, 2004).

The agency theory is rooted in economic rationality where managers seek to maximize their individual utility, rather than having other noneconomic motivations. However, wealth creation is not the only goal of family businesses. It is agreed that family firms have both economic and noneconomic goals (Chrisman et al., 2004, 2012). Corbetta and Salvato (2004) proposed that family business behaviors can instead be explained from a stewardship perspective, where family members act in ways counter to their own self-interest for the overall betterment of the firm. Stewardship theory is grounded in psychological and sociological perspectives, arguing that managers are stewards who are committed to the interests of the owners and will therefore be as diligent as owners in managing the business (Davis, Schoorman and Donaldson, 1997). As family firms are characterized by emotional attachments, long-term orientation, and the desire to hand the business to the next generation (Eddleston et al., 2012; Lumpkin, Brigham and Moss, 2010), family owners are expected to maximize the value of shares offered (Daugherty and Jithendranathan, 2012). We maintain that family members act as stewards working for the benefit of a business, thus closely monitoring the underwriter to ensure fair valuation of stocks. Indeed, the ownership structure of a firm is an important determiner of IPO value and in the case of family ownership, stewardship in family firms' effects IPO value positively (Cirillo et al., 2015).

Moreover, in family firms, the impact of emotions on firm behavior is a distinctive attribute associated with this type of organizations (Astrachan and Jaskiewicz, 2008; Zellweger and Astrachan, 2008) that results from blurring the boundaries between the family and the firm. Families are social groups that share a range of emotions because of the history and shared memories of family members (Kets de Vries and Carlock, 2010). As such, behavioral economics theories have been used in order to understand the effect of emotions in family firms. For example, Zellweger and Astrachan (2008) used the possession attachment and endowment effect of prospect theory to examine the relationship between emotional benefits and costs like organizational ownership affects emotional value. Prospect theory states that people make decisions based on the potential value of losses and gains, rather than on the final outcome, where they will tend to base their decisions on perceived gains rather than perceived losses (Kahneman and Tversky, 2013). According to the endowment effect of prospect theory, individuals place a higher value on the assets they own (willingness to accept) than they would be willing to pay (willingness to pay) to acquire the same assets (Kahneman, Knetsch and Thaler, 1990). Through their conceptual framework, Zellweger and Astrachan (2008) argued that the 


\section{Alrubaishi \& Alarifi}

added emotional value makes owners of companies subjectively value their ownership when asked the price at which they are willing to sell their firms. Moreover, Zellweger et al. (2012) utilized the prospect theory to investigate the relationship between family control and their desire to hand over the control to the next generation and the price at which family members are willing to sell their firms to non-family buyers. They found that the desire to pass the control to the next generation have a positive influence on the perceived acceptable selling price. This suggests that in light of prospect theory family members involved in managing the family firm will ask for the maximum price possible for value of the IPO, therefore, decreasing the chances of IPO underpricing. Hence, based on stewardship theory and prospect theory it is expected that family involvement in ownership and management will lead to subjectively evaluating the family firm, thus maximizing the IPO price, therefore, having a negative relationship with IPO underpricing.

$\mathrm{H}$ : Family involvement in ownership and management have a negative relationship with IPO underpricing.

\section{METHODOLOGY}

\section{-Data}

Data were collected from three sources: the Saudi stock exchange (Tadawul), the Capital Market Authority (CMA) in Saudi Arabia, and Argam.com which is an online financial news portal. The data sample consisted of both family and non-family IPOs listed at the main market of Tadawul in the period between January 1, 2007 to December 31, 2018. IPOs prior to 2007 were not included due to low market regulation before 2004 and to avoid the severe market correction in early 2006.

A total of 91 firms went public during the 6 -year period, four firms were excluded due to delisting. A further 10 firms were eliminated due to being unable to obtain their prospectus, resulting in a data set of 77 firms. Family firms are defined based on family involvement in both ownership and management. As such, family firms are those in which two or more family members possess at least 25 percent of voting rights at the time of offering. Since there does not exist a definition of family firms in Saudi Arabia, this ownership percentage is in accordance with the EU definition of listed family firms (European Commission, 2009). In addition, at least one family member should be present in the board of directors (BOD) as the participation of family members in the BOD plays a central role in underpricing (Hearn, 2011).

Each prospectus was examined to identify variables and to verify the family firms' definition stated above. Identifying owners from the same family is a relatively easy task in Saudi Arabia, as names in prospectus are reported up to the fourth name. Additionally, in accordance with Islamic laws women in 
Saudi Arabia keep their family name after marriage.

\section{-Measures}

Dependent variable: Underpricing was measured by first-day returns (the first-day closing price minus the offer price divided by the offer price).

Independent variable: The variable Family firms was measured as a dummy variable, where "1" was assigned for family firms and " 0 " otherwise.

Control variables: Several control variables commonly employed in the literature were included as they may affect the relationship under investigation. The control variables were firm size, percentage offered, oversubscription, IPO year, and industry, measured as follows:

Firm size: Natural logarithm of capital before going public.

Percentage offered: Percentage of equity offered to public.

Oversubscription: Percentage of oversubscription.

IPO year: Dummy variable that equals "1" if the firm went public in a hot issue year and " 0 " otherwise. Industry: Dummy variable that equals " 1 " if the firm is classified as a regulated industry and " 0 " otherwise.

\section{RESULTS}

The statistical analysis performed in this study included descriptive statistics of variables as well as OLS regression to test hypothesis. All analyses were carried out using SPSS (version 24) software package. The distribution of the number of IPOs over years is presented in Figure 1. Descriptive statistics of categorical and continuous variables are presented in Table 1 (see Appendix-I) and Table 2.

As shown in Figure 1, the highest number of IPOs were seen in 2007 with 15 IPOs, followed by 11 IPOs in 2008. The lowest number of IPOs were seen in 2017 with only 1 IPO. Of the 77 firms included in the analysis, 35 were family firms (45.5\%) and 42 were non-family firms (54.5\%). The average underpricing of the whole sample was 153 percent, far beyond IPO underpricing in developed and emerging markets (Ljungqvist, 2007). The average underpricing of family firms was 37 percent, whereas the average underpricing of non-family firms was 250 percent.

A hierarchical regression analysis was performed to test the hypothesis and the results are presented in Table 3 (see Appendix-II). The control variables are included in Model 1 which has an RSquared of 0.34 and an adjusted R-Squared of 0.29 . The family firm variable was added to the control variables in Model 2 and has an R-Squared of 0.40 and an adjusted R-Squared of 0.35 . For both models, the $f$-statistic is highly statistically significant and shows that taken together the 
variables included in the model have a relationship with IPO underpricing.

The following control variables: Firm's size and IPO year are statistically significantly related to underpricing at the 0.05 level. Industry is weakly positively significantly related to underpricing at the 0.10 level.

The results for Model 2 show that family firm is negatively highly statistically significant at the 0.01 level. Thus, the data support Hypothesis that family involvement in ownership and management have a negative relationship with IPO underpricing.

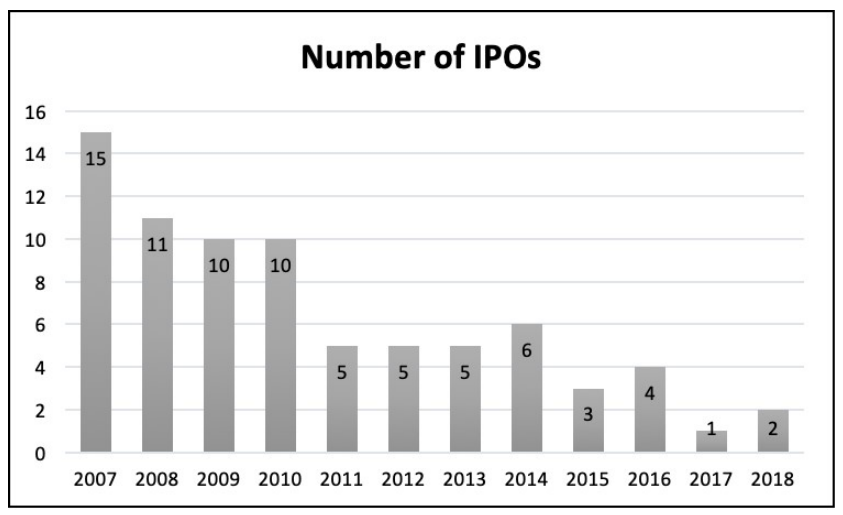

Source: Study Analysis

Figure 1. Number of IPOs in Each Year

\begin{tabular}{lcccc}
\hline & Minimum & Maximum & Mean & Std. Deviation \\
\hline Percentage Offered & 0.05 & 0.70 & 0.35 & 0.09 \\
Oversubscription & 0.83 & 23.07 & 5.89 & 4.55 \\
\hline $\begin{array}{l}\text { Source: Calculated for this study } \\
n=77\end{array}$ & & & & \\
\hline
\end{tabular}

Table 2. Descriptive Statistics for Continuous Variable

\section{CONCLUSION}

The literature on family firms IPO underpricing is inconclusive (Kotlar et al., 2018). This paper aims at providing evidence of family firms IPO underpricing in an under-research market of Saudi Arabia by utilizing a sample of 77 firms that went public in the Saudi stock market between 2007-2018 and employing a more refined definition of family firms. The findings demonstrate that the average underpricing of family firms was lower than that of non-family firms. Furthermore, the findings show 
that family involvement in ownership and management have a negative relationship with IPO underpricing supporting the study hypothesis. The results can be interpreted in light of the prospect theory and stewardship theory where family members subjectively place higher value for their firm and monitor the underwriter to ensure fair valuation of shares.

\section{IMPLICATIONS}

This study used both the prospect theory and stewardship theory to support the finding of the research. While prospect theory has been used to explain IPO underpricing of family firms, stewardship theory has been rarely used in family IPO literature. Understanding the behavior of the family management as stewards of the business has a practical implication on how the underwriters deal with the stewards.

\section{LIMITATIONS AND FUTURE DIRECTIONS}

This paper contains some limitations that may suggest possible directions for future research. First, this is a single country study; the results may not be generalized to IPOs of other similar equity markets. Future research may explore results of IPO underpricing in similar equity markets and local contexts. Second, the data collected is of a single observation for each firm, consequently, future research can monitor the performance overtime and check for differences between family and nonfamily firms. Future research may look at other variables as a proxy family firm valuation over time.

This study expands current knowledge by showing how firm ownership can affect IPO underpricing. Furthermore, the study assesses how certain characteristics of family firms affect the IPOs (e.g., family involvement in ownership and management). This study hopes to stimulate future research in family business and IPO literature, and extending our understanding of how family involvement in ownership and management affects the firm value and performance.

\section{REFERENCES}

Al-Hassan, A., Delgado, F. \& Omran, M. (2010). The under-pricing of IPOs in the Gulf cooperation council countries. Research in International Business and Finance, 24(3): 344-360.

Anderson, R. C., Duru, A. \& Reeb, D. M. (2009). Founders, heirs, and corporate opacity in the United States. Journal of Financial Economics, 92(2): 205-222.

Astrachan, J. H. \& Jaskiewicz, P. (2008). Emotional returns and emotional costs in privately held family businesses: Advancing traditional business valuation. Family Business Review, 21(2): 139-149.

Bertrand, M. \& Schoar, A. (2006). The role of family in family firms. Journal of economic perspectives, 20(2): 73-96.

Chandler, J. A., Payne, G. T., Moore, C. \& Brigham, K. H. (2019). Family involvement signals in initial public offerings. Journal of Family Business Strategy, 10(1): 8-16.

Chrisman, J. J., Chua, J. H. \& Litz, R. A. (2004). Comparing the agency costs of family and non-family firms: Conceptual issues and exploratory evidence. Entrepreneurship Theory and Practice, 28(4): 335-354.

Chrisman, J. J., Chua, J. H., Pearson, A. W. \& Barnett, T. (2012). Family involvement, family influence, and family-centered non-economic goals in small firms. Entrepreneurship theory and practice, 36(2): 267-293. 


\section{Alrubaishi \& Alarifi}

Cirillo, A., Romano, M. \& Ardovino, O. (2015). Does family involvement foster IPO value? Empirical analysis on Italian stock market. Management Decision, 53(5): 1125-1154.

Combs, J. G., Penney, C. R., Crook, T. R. \& Short, J. C. (2010). The impact of family representation on CEO compensation. Entrepreneurship Theory and Practice, 34(6): 1125-1144.

Corbetta, G. \& Salvato, C. (2004). Self-serving or self-actualizing? Models of man and agency costs in different types of family firms: A commentary on "comparing the agency costs of family and non-family firms: Conceptual issues and exploratory evidence". Entrepreneurship Theory and Practice, 28(4): 355-362.

Cruz, C. \& Nordqvist, M. (2012). Entrepreneurial orientation in family firms: A generational perspective. Small Business Economics, 38(1): 33-49.

Daugherty, M. S. \& Jithendranathan, T. (2012). Underpricing of IPOS of US family controlled businesses. Finance Faculty Publications, Paper no.12.

Davis, J. H., Schoorman, F. D. \& Donaldson, L. (1997). Toward a stewardship theory of management. Academy of Management Review, 22(1): 20-47.

Duran, P., van Essen, M., Heugens, P. P., Kostova, T. \& Peng, M. W. (2019). The impact of institutions on the competitive advantage of publicly listed family firms in emerging markets. Global Strategy Journal, 9(2): 243-274.

Eddleston, K. A., Kellermanns, F. W. \& Zellweger, T. M. (2012). Exploring the entrepreneurial behavior of family firms: does the stewardship perspective explain differences? Entrepreneurship Theory and Practice, 36(2): 347-367.

European Commission (2009). Overview of family business relevant issues: research, networks, policy measures and existing studies. Retrieved February 2019, from https://ec.europa.eu/docsroom/documents/10 388 /attachments/1/translations/en/ renditions/pdf

Fama, E. F. \& Jensen, M. C. (1983). Separation of ownership and control. The Journal of Law and Economics, 26(2): 301325.

Filatotchev, I. \& Bishop, K. (2002). Board composition, share ownership, and 'underpricing' of UK IPO firms. Strategic Management Journal, 23(10): 941-955.

Hearn, B. (2011). The performance and the effects of family control in North African IPOs. International Review of Financial Analysis, 20(3): 140-151.

Jensen, M. C. \& Meckling, W. H. (1976). Theory of the firm: Managerial behavior, agency costs and ownership structure. Journal of Financial Economics, 3(4): 305-360.

Kahneman, D. \& Tversky, A. (2013). Prospect theory: An analysis of decision under risk. In MacLean, L. C., \& Ziemba, W. T. (Eds.), Handbook of the fundamentals of financial decision making: 99-127. World Scientific.

Kahneman, D., Knetsch, J. L. \& Thaler, R. H. (1990). Experimental tests of the endowment effect and the Coase theorem. Journal of Political Economy, 98(6): 1325-1348.

Kets de Vries, M. F. K. \& Carlock, R. S. (2010). Family business on the couch: A psychological perspective. England: John Wiley \& Sons.

Kiymaz, H. (2000). The initial and aftermarket performance of IPOs in an emerging market: evidence from Istanbul stock exchange. Journal of Multinational Financial Management, 10(2): 213-227.

Kotlar, J., Signori, A., De Massis, A. \& Vismara, S. (2018). Financial wealth, socioemotional wealth, and IPO underpricing in family firms: A two-stage gamble model. Academy of Management Journal, 61(3): 1073-1099.

La Porta, R., Lopez-de-Silanes, F. \& Shleifer, A. (1999). Corporate ownership around the world. The Journal of Finance, 54(2): $471-517$

Le Breton-Miller, I., Miller, D. \& Lester, R. H. (2011). Stewardship or agency? A social embeddedness reconciliation of conduct and performance in public family businesses. Organization Science, 22(3): 704-721.

Lien, Y. C. \& Li, S. (2014). Professionalization of family business and performance effect. Family Business Review, 27(4): 346-364.

Leitterstorf, M. P. \& Rau, S. B. (2014). Socioemotional wealth and IPO underpricing of family firms. Strategic Management Journal, 35(5): 751-760

Ljungqvist, A. (2007). IPO Underpricing. In Eckbo, B. E. (Ed.), Handbook of Corporate Finance: Empirical Corporate Finance: 375-418. North-Holland: Elsevier.

Loughran, T. \& Ritter, J. R. (2002). Why don't issuers get upset about leaving money on the table in IPOs? The Review of Financial Studies, 15(2): 413-444.

Loughran, T., Ritter, J. R. \& Rydqvist, K. (1994). Initial public offerings: International insights. Pacific-Basin Finance Journal, 2(2-3): 165-199.

Lumpkin, G. T., Brigham, K. H. \& Moss, T. W. (2010). Long-term orientation: Implications for the entrepreneurial orientation and performance of family businesses. Entrepreneurship and Regional Development, 22(3-4): 241-264.

Miller, D., Le Breton-Miller, I., Lester, R. H. \& Cannella Jr, A. A. (2007). Are family firms really superior performers? Journal of Corporate Finance, 13(5): 829-858.

Minichilli, A., Brogi, M. \& Calabrò, A. (2016). Weathering the storm: Family ownership, governance, and performance through the financial and economic crisis. Corporate Governance: An International Review, 24(6): 552-568

Mullins, W. \& Schoar, A. (2016). How do CEOs see their roles? Management philosophies and styles in family and non-family firms. Journal of Financial Economics, 119(1): 24-43.

Naldi, L., Nordqvist, M., Sjöberg, K. \& Wiklund, J. (2007). Entrepreneurial orientation, risk taking, and performance in family firms. Family Business Review, 20(1): 33-47.

Ramadani, V. \& Gërguri-Rashiti, S. (2017). Global marketing, gender and family business in Asia: A literature review. Journal of Global Marketing, 30(3): 138-146. 
International Journal of Management, Economics and Social Sciences

Sharma, P. (2004). An overview of the field of family business studies: Current status and directions for the future. Family Business Review, 17(1): 1-36.

Signori, A., Kotlar, J., De Massis, A. \& Vismara, S. (2015). Rate of substitution between economic and socioemotional wealth in family firm IPO underpricing. Academy of Management Proceedings, 1, 12090.

Schepers, J., Voordeckers, W., Steijvers, T. \& Laveren, E. (2014). The entrepreneurial orientation-performance relationship in private family firms: the moderating role of socioemotional wealth. Small Business Economics, 43(1): 39-55.

Sonfield, M. C. \& Lussier, R. N. (2004). First-, second-, and third-generation family firms: A comparison. Family Business Review, 17(3): 189-201.

The Ministry of Commerce and Investment (2018). The Minister of Commerce and Investment Inaugurates the National Center for Family Enterprises. Retrieved February 2019, from https://mci.gov.sa/en/MediaCenter/News/Pages/04-11-18-01.aspx.

Westin, E. \& Wiklund, S. (2016). IPO underpricing and ownership structure: A comparison of family firms and non-family firms. (Published Master's Thesis). Uppsala University, Uppsala, Sweden.

Zahra, S. A., Hayton, J. C., Neubaum, D. O., Dibrell, C. \& Craig, J. (2008). Culture of family commitment and strategic flexibility: The moderating effect of stewardship. Entrepreneurship Theory and Practice, 32(6): 1035-1054.

Zellweger, T. M. \& Astrachan, J. H. (2008). On the emotional value of owning a firm. Family Business Review, 21(4): $347-363$.

Zellweger, T. M., Kellermanns, F. W., Chrisman, J. J. \& Chua, J. H. (2012). Family control and family firm valuation by family CEOs: The importance of intentions for transgenerational control. Organization Science, 23(3): 851-868. 


\begin{tabular}{|c|c|c|}
\hline & Frequency & Percen \\
\hline \multicolumn{3}{|c|}{ IPO Year } \\
\hline 2007 & 15 & 19.5 \\
\hline 2008 & 11 & 14.3 \\
\hline 2009 & 10 & 13.0 \\
\hline 2010 & 10 & 13.0 \\
\hline 2011 & 5 & 6.5 \\
\hline 2012 & 5 & 6.5 \\
\hline 2013 & 5 & 6.5 \\
\hline 2014 & 6 & 7.8 \\
\hline 2015 & 3 & 3.9 \\
\hline 2016 & 4 & 5.2 \\
\hline 2017 & 1 & 1.3 \\
\hline 2018 & 2 & 2.6 \\
\hline \multicolumn{3}{|c|}{ Industry } \\
\hline Regulated & 39 & 50.6 \\
\hline Non-regulated & 38 & 49.4 \\
\hline \multicolumn{3}{|c|}{ Family/ Non-family Firms } \\
\hline Family Firms & 35 & 45.5 \\
\hline Non-Family Firms & 42 & 54.5 \\
\hline
\end{tabular}

Table 1. Descriptive Statistics for Categorical Variables 


\begin{tabular}{|c|c|c|}
\hline & Model 1 & Model 2 \\
\hline Firm Size & $-.30(.17)^{\dagger}$ & $-.37(.16)^{*}$ \\
\hline IPO Year & $1.95(.59)^{* * *}$ & $1.56(.58) * *$ \\
\hline Oversubscription & $.04(.05)$ & $.03(.05)$ \\
\hline Industry & $1.31(.51)^{* *}$ & $.90(.51)^{\dagger}$ \\
\hline Percentage Offered & $3.58(2.64)$ & $-.16(2.88)$ \\
\hline Family Firms & --------- & $-1.52(.56) *$ \\
\hline Constant & $4.93(3.57)$ & $8.54(3.67)$ ** \\
\hline$f$-test & $7.17^{* * *}$ & $7.74^{* * *}$ \\
\hline$R^{2}$ & 0.34 & 0.40 \\
\hline Adjusted $R^{2}$ & 0.29 & 0.35 \\
\hline
\end{tabular}

Source: Calculated for this study

$n=77 ; \uparrow p<.10 ; * p<.05 ; *^{*} p<.01 ; * * * p<.001$

Table 3. Regression Models of IPO Underpricing 